\title{
RESEARCH ON WATER DEMAND RULES AND YIELD OF MULTI-STOREY CROPPING HERBAGE GROUPS UNDER WATER STRESS CONDITIONS
}

\author{
LIU, H. ${ }^{1,2,4}-$ WEI, Z. ${ }^{1 *}-$ YIN, C. ${ }^{3 *}-$ WEI, Y. ${ }^{2}-$ ZHAO, S. ${ }^{2}-$ ZHANG, R. ${ }^{2}-$ WANG J. ${ }^{2}-$ ZHAO J. ${ }^{3}$ \\ ${ }^{1}$ Inner Mongolia Agricultural University \\ No. 306 Zhaowuda Road, Hohhot City, Inner Mongolia, China \\ (phonelfax: +86-471-431-9291) \\ ${ }^{2}$ Institute of Water Resources for Pastoral Area Ministry of Water Resources \\ No. 128 University East Street, Saihan District, Hohhot City, Inner Mongolia, China \\ (phone: +86-471-469-0607; fax: +86-471-495-1331)
}

${ }^{3}$ Inner Mongolia Academy of Agricultural and Animal Husbandry Sciences

No. 22 Zhaojun Road, Yuquan District, Hohhot City, Inner Mongolia, China

(phone/fax: +86-471-590-0262)

${ }^{4}$ State Key Laboratory of Simulation and Regulation of Water Cycle in River Basin

Room 936, Block D, No. 1 Fuxing Road, Haidian District, Beijing, China

(phonelfax: +86-10-68781380)

*Corresponding author

e-mail: 444841507@qq.com; phonelfax: +86-471-590-0262

(Received $11^{\text {th }}$ Jan 2019; accepted $8^{\text {th }}$ Mar 2019)

\begin{abstract}
It is greatly significant to implement water-saving irrigation and establish a water-saving system for forage grass, on basis of non-full irrigation principles, in order to meet the demands for forage grass from the rapidly-developing Chinese dairy industry distributing in rural-urban fringes, and improve the utilization efficiency of limited water resources in the central dairy production area of Inner Mongolia. The paper targets four different planting patterns of maize/alfalfa, and discusses water demand rules of herbage groups, variation of evapotranspiration, influence of water shortage at different stages on evapotranspiration, and moisture sensitive period of the forage grass under multi-storey cropping conditions, based on the experimental data of forage multi-storey cropping field under different water stress conditions in the outskirts of Hohhot. According to the results, the change in water demand of maize/alfalfa belt type multi-storey cropping field presents a wavy rule during the whole growth period; compared to evapotranspiration of monocropping maize/alfalfa, the evapotranspiration of maize/alfalfa multi-storey cropping herbage group was not significantly variable. The moisture sensitive period of monoculture maize and alfalfa were respectively heading-milk ripe stage and branching-squaring stage, and the moisture sensitive period of 4//8-type multi-storey cropping pattern is branching-jointing stage.

Keywords: water-saving irrigation, moisture sensitive period, designed moisting layer, water utilization efficiency, evapotranspiration, moisture sensitive period, water balance equation, modal coefficient
\end{abstract}

\section{Introduction}

The development level of the dairy industry is deemed as a significant indicator of the quality of modern agriculture in a country, especially animal husbandry. Dairy industry is recognized as a food-saving, economic and efficient industry, among the animal by-products with the highest forage conversion intensity. The World Health Organization regards the average dairy consumption of the population as one of the key indicators to measure the standard of living of the people in a country, and many 
countries worldwide, including China. In order to meet the demands for forage grass from the rapidly-developing Chinese dairy industry, it is very significant to research water-saving technologies on basis of non-full irrigation principles, implement watersaving irrigation on dairy forage grass, and improve utilization efficiency of limited water resources in production. Meanwhile, dairy industry mainly distributes in ruralurban fringes, the evapotranspiration for forage production and irrigation has been exhausting urban water resources, the proper distribution of limited water resources will become a critical issue in water management (Zhou et al., 2015; Wang et al., 2003; Chen et al., 1997; Li et al., 2003; Guo et al., 2005; Zhang et al., 2002; Zhao et al., 2008; Liu and Yin, 2013; Liu et al., 2016).

In Hohhot, well-known as "Chinese Dairy City", the high-quality forage cultivated area reached $173,000 \mathrm{hm}^{2}$ in 2006 , accounting for $33 \%$ of the city's total arable land area. The paper analyzes the experimental data of forage multi-storey cropping field under different water stress conditions in the outskirts of Hohhot from 2011 to 2015, discusses water demand rules of herbage groups, variation of evapotranspiration, influence of water shortage at different stages of evapotranspiration, and determines the moisture sensitive period of the forage grass under multi-storey cropping conditions, based on analyzing the forage crops yield under different moisture treatment conditions. The research results provide the basis for the implementation of scientific water management on dairy forage production in Hohhot and even central Inner Mongolia.

\section{Materials and methods}

\section{Experimental region}

The experiment was conducted in Agricultural Technology Demonstration Park, Xigoumen Town, with coordinates of E111 59'38.97', N40 37'56.48'. The experimental region is located in semi-arid temperate continental monsoon climate zone, the soil is sandy loam, the mass ratio of organic matter, total nitrogen and total phosphorus is respectively $1.0 \%, 0.7 \%$ and $0.1 \%$, the dry bulk density is $1.4 \mathrm{~g} / \mathrm{cm}^{3}$ and the field capacity is $22.2 \%$.

\section{Experimental design}

The experimental materials adopt feed \& storage dual-purpose type Jinshan No. 1 maize and mow-resistant high-protein content algonquin alfalfa, control index of soil moisture shown in Table 1. By adopting field comparison experimental method, total four kinds of crop combinations is planted, including monoculture maize, monoculture alfalfa, 2 rows of maize intercropped with 12 rows of alfalfa (2//12 type), 4 rows of maize intercropped with 8 rows of alfalfa (4//8 type). The total 17 treatment means are implemented, each treatment is made three times, each unit area is $32 \mathrm{~m}^{2}$ as shown in Table 2. As for $2 / / 12$ type, the alfalfa/maize belt width is $2.4 \mathrm{~m}$ and $0.8 \mathrm{~m}$, as for the 4//8 type, the alfalfa/maize belt width is $1.6 \mathrm{~m}$, as for monoculture alfalfa/maize field, the belt width is $3.2 \mathrm{~m}$. The climate condition is divided into non-drought and moderate drought, the soil moisture is regarded as the control index. Experimental photograph was shown in Figure 1. 
Table 1. Control index of soil moisture. (Unit: field capacity \%)

\begin{tabular}{c|c|c|c}
\hline Experimental level & Maize monoculture & Alfalfa monoculture & $\begin{array}{c}\text { Maize and alfalfa multi-storey } \\
\text { cropping }\end{array}$ \\
\hline $\begin{array}{c}\text { Non-drought } \\
\text { Moderate drought }\end{array}$ & 70 & 65 & 65 \\
$40 \sim 50$ & $40 \sim 50$ & $40 \sim 50$ \\
\hline
\end{tabular}

The moisture is a lower-limit value, the field capacity is an upper limit

Table 2. Experimental design for forage moisture stress

\begin{tabular}{|c|c|c|c|c|c|}
\hline \multirow[b]{2}{*}{ Trt. } & \multirow[b]{2}{*}{ Patterns } & \multicolumn{4}{|c|}{ Moisture treatment } \\
\hline & & $\begin{array}{c}\text { Sprouting-tillering period } \\
\text { (sprouting (seedling establishment)- } \\
\text { branching) }\end{array}$ & $\begin{array}{c}\text { Tillering-jointing } \\
\text { period } \\
\text { (branching-squaring) }\end{array}$ & $\begin{array}{c}\text { Heading-flowering } \\
\text { period } \\
\text { (squaring-flowering) } \\
\end{array}$ & $\begin{array}{c}\text { Grouting-mature } \\
\text { period }\end{array}$ \\
\hline 1 & \multirow{5}{*}{$\begin{array}{c}\text { Maize } \\
\text { monoculture }\end{array}$} & Non-drought & Non-drought & Non-drought & Non-drought \\
\hline 2 & & Moderate drought & Non-drought & Non-drought & Non-drought \\
\hline 3 & & Non-drought & Moderate drought & Non-drought & Non-drought \\
\hline 4 & & Non-drought & Non-drought & Moderate drought & Non-drought \\
\hline 5 & & Non-drought & Non-drought & Non-drought & Moderate drought \\
\hline 6 & \multirow{4}{*}{$\begin{array}{c}\text { Alfalfa } \\
\text { monoculture }\end{array}$} & Non-drought & Non-drought & Non-drought & \\
\hline 7 & & Moderate drought & Non-drought & Non-drought & \\
\hline 8 & & Non-drought & Moderate drought & Non-drought & \\
\hline 9 & & Non-drought & Non-drought & Moderate drought & \\
\hline 10 & \multirow{4}{*}{ 2//12 type } & Non-drought & Non-drought & Non-drought & \\
\hline 11 & & Moderate drought & Non-drought & Non-drought & \\
\hline 12 & & Non-drought & Moderate drought & Non-drought & \\
\hline 13 & & Non-drought & Non-drought & Moderate drought & \\
\hline 14 & \multirow{4}{*}{ 4//8 type } & Non-drought & Non-drought & Non-drought & \\
\hline 15 & & Moderate drought & Non-drought & Non-drought & \\
\hline 16 & & Non-drought & Moderate drought & Non-drought & \\
\hline 17 & & Non-drought & Non-drought & Moderate drought & \\
\hline
\end{tabular}

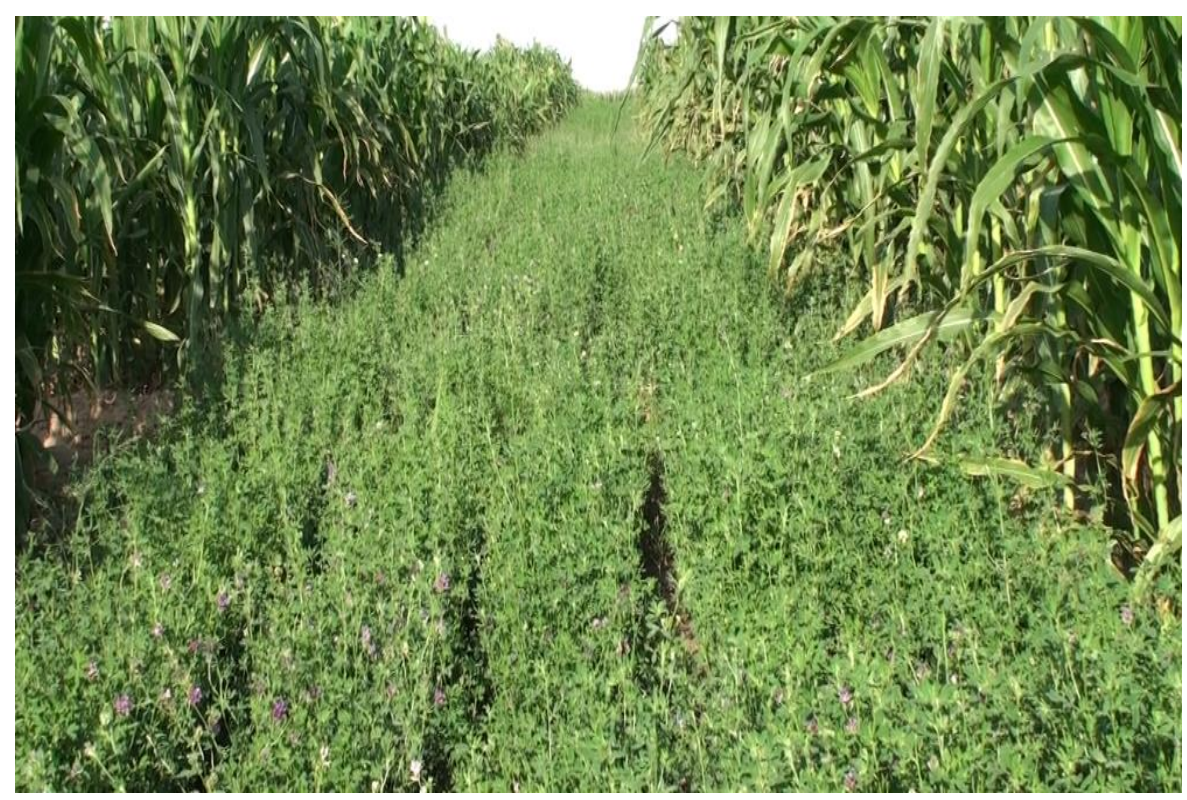

Figure 1. Experimental photograph (heading-flowering period of maize and squaring-of alfalfa) 


\section{Experimental data acquisition}

The meteorological data is obtained and purchased from local meteorological bureau. It is available to sample soil by manual earth boring auger, and determine soil water content by drying and weighing method. The quadrates is adopted to measure the yield before harvest. The tube irrigation method is adopted to record time, the meter is adopted to record irrigation water yield.

\section{Results and analysis}

\section{Characteristic of water demand of forage groups under different planting patterns}

In accordance with the principle of water balance, in any period of the whole growth term $(t)$, the changes in moisture storage capacity in soil designed moisting layer $(h)$ is expressed by the following water balance equation:

$$
W_{t}-W_{0}=W_{r}+P_{0}+K+M+E T_{a}
$$

In Equation 1, $W_{0}, W_{t}$ represents moisture storage capacity in soil designed moisting layer at the beginning of time interval and at any time $t ; W r$ represents increased moisture storage capacity due to increase of soil designed moisting layer, if the soil designed moisting layer does not change, the option can be ignored; $P_{0}$ is rainfall; $K$ is groundwater recharge within the period $t$, if in the experimental region, the groundwater level is below $10 \mathrm{~m}$ within a long period, $K$ should be equal to $0 ; M$ is the irrigation water volume within the period t; $E T_{a}$ is the actual evapotranspiration.

Table 3 show the actual evapotranspiration and rules of water demand of maize/ alfalfa forage group of different cropping patterns under full irrigation conditions according to Equation 1.

Table 3. Forage group evapotranspiration of different planting pattern

\begin{tabular}{|c|c|c|c|c|c|c|c|c|c|c|c|}
\hline \multirow{6}{*}{ Trt. } & \multicolumn{2}{|r|}{ Items } & \multicolumn{9}{|c|}{ Main technical parameters } \\
\hline & \multirow{3}{*}{ Alfalfa } & \multirow[b]{2}{*}{ Growth period } & \multicolumn{4}{|c|}{ Crop 1} & \multicolumn{3}{|c|}{ Crop 2} & \multirow{2}{*}{$\begin{array}{c}\text { Crop 3 } \\
\begin{array}{c}\text { Seedling } \\
\text { establishment- } \\
\text { branching }\end{array} \\
\end{array}$} & \multirow[b]{2}{*}{$\begin{array}{l}\text { Whole } \\
\text { growth } \\
\text { period }\end{array}$} \\
\hline & & & $\begin{array}{l}\text { Seeding- } \\
\text { sprouting }\end{array}$ & $\begin{array}{l}\text { Sprouting- } \\
\text { branching }\end{array}$ & $\begin{array}{c}\text { Branching- } \\
\text { squaring }\end{array}$ & \begin{tabular}{|l|} 
Squaring- \\
flowering \\
(clipping)
\end{tabular} & $\begin{array}{c}\text { Seedling } \\
\text { establishment- } \\
\text { branching }\end{array}$ & $\begin{array}{l}\text { Branching- } \\
\text { squaring }\end{array}$ & $\begin{array}{l}\text { Heading- } \\
\text { flowering } \\
\text { (clipping) }\end{array}$ & & \\
\hline & & Rainfall (mm) & 25.6 & 34.4 & 29.2 & 62.6 & 134.2 & 48.4 & 6.6 & 16.5 & 357.5 \\
\hline & \multirow[t]{2}{*}{ Maize } & Growth period & \begin{tabular}{|l|} 
Seeding- \\
sprouting
\end{tabular} & $\begin{array}{c}\text { Sprouting- } \\
\text { jointing }\end{array}$ & $\begin{array}{l}\text { Jointing- } \\
\text { heading }\end{array}$ & \multicolumn{3}{|c|}{ Heading-milking maturity } & $\begin{array}{c}\text { Milking maturity- } \\
\text { soft dough }\end{array}$ & & \\
\hline & & Rainfall (mm) & 21.5 & 44.6 & 48.6 & \multicolumn{3}{|c|}{224.6} & 11.9 & & 351.2 \\
\hline \multirow{4}{*}{6} & & oil Moisture & $19.1-18.4$ & $18.4-16.8$ & $16.8-17.3$ & $17.3 \sim 17.3$ & $17.3-20.1$ & $20.1-12.8$ & $12.8-16.2$ & $14.9-15.9$ & \\
\hline & Irrige & ion amount $(\mathrm{mm})$ & & & 100 & 70 & & & 120 & 70 & \\
\hline & Consum & tion intensity $(\mathrm{mm} / \mathrm{d})$ & 2.15 & 2.65 & 4.78 & 6.87 & 3.25 & 7.45 & 6.95 & 2.15 & 3.92 \\
\hline & Evapc & transpiration $(\mathrm{mm})$ & 32.3 & 47.7 & 124.3 & 137.4 & 39 & 111.8 & 97.3 & 32.3 & 726.7 \\
\hline \multirow{4}{*}{1} & & Soil moisture & $19.2-20.0$ & $20.0-19.9$ & $19.9-14.0$ & \multirow{2}{*}{\multicolumn{3}{|c|}{$\begin{array}{c}14.0-14.1 \\
180\end{array}$}} & $14.1-13.5$ & & \\
\hline & Irrige & ion amount $(\mathrm{mm})$ & & 70 & 120 & & & & 80 & & \\
\hline & Consum & tion intensity $(\mathrm{mm} / \mathrm{d})$ & 1.82 & 3.05 & 6.65 & & 8.25 & & 6.45 & & 5.95 \\
\hline & Evapc & transpiration $(\mathrm{mm})$ & 17.6 & 92.4 & 124.5 & & 289.6 & & 76.5 & & 600.6 \\
\hline \multirow{4}{*}{10} & & boil moisture & 20.0-19.6 & $19.6-17.8$ & $17.8-19.0$ & $19.0-17.5$ & $17.5-20.3$ & $20.3-18.0$ & $18.0-17.4$ & $17.4-16.1$ & \\
\hline & Irrige & tion amount $(\mathrm{mm})$ & & & 70 & 80 & & 100 & 100 & 120 & \\
\hline & Consum & tion intensity $(\mathrm{mm} / \mathrm{d})$ & 1.91 & 3.27 & 4.78 & 8.77 & 2.44 & 5.59 & 6.58 & 3.65 & 3.49 \\
\hline & Evap & transpiration $(\mathrm{mm})$ & 28.6 & 58.9 & 124.4 & 175.5 & 29.3 & 83.9 & 92.1 & 54.8 & 647.3 \\
\hline \multirow{4}{*}{14} & & oil moisture & $18.9-18.4$ & $18.4-16.7$ & $16.7-17.7$ & $17.7-16.5$ & $16.5-20.3$ & 20.3-16.15 & $16.2-15.4$ & 54.8 & \\
\hline & Irrige & ion amount (mm) & & & 70 & 80 & & 100 & 100 & 120 & \\
\hline & Consum & tion intensity $(\mathrm{mm} / \mathrm{d})$ & 2.0 & 2.9 & 5.7 & 7.6 & 4.9 & 7.5 & 6.9 & 4.4 & 3.6 \\
\hline & Evapc & transpiration (mm) & 29.8 & 49.6 & 98.5 & 151.0 & 57.3 & 112.4 & 96.3 & 65.7 & 660.5 \\
\hline
\end{tabular}

The percentage of soil moisture in the total soil dry weight, $\%$ 
Under full-irrigation conditions, the evapotranspiration of monoculture alfalfa is $726.7 \mathrm{~mm}$ as the maximum value, and the evapotranspiration of monoculture maize is $600.6 \mathrm{~mm}$ as the minimum value, the maize/alfalfa multi-storey cropping evapotranspiration is between the above data, the growing season of monoculture alfalfa within a year is longer than the monoculture maize, the evapotranspiration of monoculture alfalfa is also higher than the monoculture maize during the whole growth period; because mowing is implemented several times a year, evapotranspiration intensity is peaked with alfalfa mowing frequency, each peak occurs in alfalfa squaringflowering stage, the maximum peak occurs between the first mowing and the Secord mowing, during the branching-squaring stage, the evapotranspiration of alfalfa is maximum, accounting for $40.0 \%$ of the whole growth period; during the headingmilking stage, the evapotranspiration of monoculture maize is up to $289.6 \mathrm{~mm}$, accounting for $48.2 \%$ of the whole growth period. The growing season of monoculture maize is relatively short, during the whole growth period, its total evapotranspiration is also lower than the monoculture alfalfa and multi-storey cropping alfalfa; the water demand rules show a single peak, the consumption intensity during heading-milking stage is maximum. The evapotranspiration of maize//alfalfa belt-type multi-storey cropping during the whole growth is greater than the monoculture maize; and is closer to monoculture alfalfa; the water demand rules of herbage group is impacted by alfalfa mowing, its evapotranspiration intensity is considerably unstable, the fluctuation trend is similar with monoculture alfalfa.

\section{Variation analysis of evapotranspiration of forage grass under multi-storey cropping conditions}

Because the dynamic evapotranspiration and evapotranspiration trend of forage grass has changed, the evapotranspiration of maize//alfalfa multi-storey cropping forage grass should not be equal to the sum of evapotranspiration of both two plants, the degree of variation (variability) is calculated by the following formula:

$$
C_{v}=\sum_{i=1}^{n} \frac{\sqrt{(x-\bar{x})^{2}}}{x}
$$

In the formula: $C_{v}$-variability; $x$-sample evapotranspiration; $x$-arithmetic mean of the two samples. The evapotranspiration indicators under monoculture conditions are taken as standard samples, the evapotranspiration indicators under multi-storey cropping are taken as comparison samples; $C_{v^{-}}$the degree of variation of multi-storey cropping for monoculture.

The evapotranspiration variability calculated by Equation 2 under the multi-storey cropping conditions are shown in Table 4. The results show that the evapotranspiration of forage grass group is not significantly variable from the evapotranspiration of monoculture maize and monoculture alfalfa, the variability is respectively 0.037 and 0.040, however, it is significantly variable, compared with monoculture alfalfa.

\section{Evapotranspiration (ET) of monoculture maize under phased water shortage conditions}

Under the maize monoculture conditions, the different water treatment has a significant impact on evapotranspiration. The treatment 4 is the water shortage at 
heading-milking stage, the change in total evapotranspiration is the most obvious during the whole growth period, according for $75 \%$ of treatment 1 . The treatment 2 is the water shortage at sprouting-jointing stage, the change in total evapotranspiration is minimum, according for $85 \%$ of treatment 1 . In case of water shortage at a certain stage, the treatment may cause the increase of evapotranspiration at the next stage, there is a certain compensation effect, in this experiment, during the sprouting-jointing stage and heading-milking stage, the compensation effect for low moisture treatment is more obvious.

Table 4. Analysis on variation of ET of maize \& alfalfa under multi-storey cropping conditions

\begin{tabular}{c|c|c|c}
\hline Samples & Treatments & $\boldsymbol{E T}(\mathbf{m m})$ & $\boldsymbol{C}_{\boldsymbol{v}}$ \\
\hline \multirow{2}{*}{ Standard samples } & 1 & 600.6 & 0.0370 \\
& 6 & 726.7 & 0.0403 \\
\hline Comparison samples & 14 & 660.5 & \\
\hline
\end{tabular}

\section{Water shortage at different growth stages on evapotranspiration of forage groups}

It is found from Table 5 that the evapotranspiration at various growth stages under different water treatments is less at the preliminary stage, increase at the interim stage, the late small variation, and then decreases at the later stage, which mainly result from the growth and development of maize plants and influence from environment meteorological factors, the moisture shortage also affects daily evapotranspiration intensity, thereby affects the evapotranspiration at the reproductive stage. Treatment 2 and 3 is the drought conditions respectively at seedling/jointing stage, at this time, the maize seedling size is less, the evapotranspiration is less. At the heading-milking stage, the evapotranspiration of fully-irrigated treatment is maximum, other treatments are water deficit at other growth stages, although after rewatering in this stage, evapotranspiration increases obviously, but is always lower than treatment 1 , because the jointing-heading stage is the peak of the growth of maize silage, if water deficit exists during this period, the growth of plants will be seriously affected, resulting in a less silage maize leaf area index, the plant evapotranspiration is less than other treatments; on the other hand, even if the stage is not affected by the drought, but before the stage have been affected, resulting in poor plant growth, and the evapotranspiration intensity and evapotranspiration will be ultimately affected in the later stage of treatment.

Table 5. Maize straw of different water treatment on evapotranspiration

\begin{tabular}{c|c|c|c|c|c|c|c|c|c|c|c}
\hline \multirow{2}{*}{ Trt } & \multicolumn{2}{|c|}{ Seeding-sprouting } & \multicolumn{2}{|c|}{ Sprouting-jointing } & \multicolumn{2}{|c|}{ Jointing-heading } & \multicolumn{2}{|c|}{$\begin{array}{c}\text { Heading-milking } \\
\text { maturity }\end{array}$} & \multicolumn{2}{|c|}{$\begin{array}{c}\text { Milking maturity- } \\
\text { soft dough }\end{array}$} & $\begin{array}{c}\text { Whole } \\
\text { growth }\end{array}$ \\
\cline { 2 - 11 } & $\begin{array}{c}\text { ET } \\
(\mathbf{m m})\end{array}$ & $\begin{array}{c}\text { Modal } \\
\text { coefficient } \\
(\boldsymbol{\%})\end{array}$ & $\begin{array}{c}\text { ET } \\
(\mathbf{m m})\end{array}$ & $\begin{array}{c}\text { Modal } \\
\text { coefficient } \\
(\boldsymbol{\%})\end{array}$ & $\begin{array}{c}\mathbf{E T} \\
(\mathbf{m m})\end{array}$ & $\begin{array}{c}\text { Modal } \\
\text { coefficient } \\
(\boldsymbol{\%})\end{array}$ & $\begin{array}{c}\text { ET } \\
(\mathbf{m m})\end{array}$ & $\begin{array}{c}\text { Modal } \\
\text { coefficient } \\
(\boldsymbol{\%})\end{array}$ & $\begin{array}{c}\text { ET } \\
(\mathbf{m m})\end{array}$ & $\begin{array}{c}\text { Modal } \\
\text { coefficient } \\
(\boldsymbol{\%})\end{array}$ & $\begin{array}{c}\text { period } \\
(\mathbf{m m})\end{array}$ \\
\hline 1 & 17.6 & 2.9 & 92.4 & 15.4 & 124.5 & 20.7 & 289.6 & 48.2 & 76.5 & 12.7 & 600.6 \\
2 & 10.2 & 2 & 23.0 & 4.5 & 152.6 & 29.9 & 246.1 & 48.2 & 78.6 & 15.4 & 510.5 \\
3 & 8.8 & 2 & 66.2 & 15.1 & 52.2 & 11.9 & 247.3 & 56.4 & 64.0 & 14.6 & 438.4 \\
4 & 8.6 & 1.9 & 63.5 & 14.1 & 114.9 & 25.5 & 134.2 & 29.8 & 129.3 & 28.7 & 450.5 \\
5 & 9.1 & 1.9 & 67.3 & 14 & 107.2 & 22.3 & 240.7 & 50.1 & 56.2 & 11.7 & 480.5 \\
\hline
\end{tabular}




\section{Evapotranspiration of monoculture alfalfa under phased water shortage conditions}

Table 6 shows, the alfalfa high evapotranspiration period is between in the first crop and the second crop, in the stage, the evapotranspiration accounts for $47.82 \%$ and $40.49 \%$ of total amount of the whole growth period, under full-irrigation conditions. The low moisture treatments in seedling (seedling establishment)-branching, branchingsquaring, squaring-flowering, and other growth stages has a great influence on the total evapotranspiration during the whole growth period, compared to treatment 1 , the low moisture treatment at the branching-squaring stage decreases by $20 \%$; at seedling (seedling establishment)-branching stage, the total evapotranspiration of whole growth period changes less, however, it can decrease by $18 \%$, compared with treatment 6 .

Table 6. Evapotranspiration of monoculture alfalfa and maizelalfalfa intercropping at different water treatments

\begin{tabular}{c|c|c|c|c|c|c|c}
\hline \multirow{2}{*}{ Trt } & \multicolumn{2}{|c|}{ Crop 1 } & \multicolumn{2}{c|}{ Crop 2 } & \multicolumn{2}{|c|}{ Crop 3 } & Total \\
\cline { 2 - 7 } & $\begin{array}{c}\text { ET } \\
(\mathbf{m m})\end{array}$ & $\begin{array}{c}\text { Modal } \\
\text { coefficient }(\boldsymbol{\%})\end{array}$ & $\begin{array}{c}\text { ET } \\
(\mathbf{m m})\end{array}$ & $\begin{array}{c}\text { Modal } \\
\text { Coefficient }(\boldsymbol{\%})\end{array}$ & $\begin{array}{c}\text { ET } \\
(\mathbf{m m})\end{array}$ & $\begin{array}{c}\text { Modal } \\
\text { coefficient }(\boldsymbol{\%})\end{array}$ & $\begin{array}{c}\text { ET } \\
(\mathbf{m m})\end{array}$ \\
\hline 6 & 347.5 & 45.9 & 294.3 & 38.8 & 84.9 & 11.2 & 726.7 \\
7 & 250.1 & 40.5 & 266.2 & 43.1 & 76.6 & 12.4 & 592.9 \\
8 & 270.2 & 44.7 & 206.0 & 34.1 & 103.5 & 17.1 & 579.7 \\
9 & 262.1 & 43.1 & 229.5 & 37.8 & 91.5 & 15.1 & 583.1 \\
\hline 14 & 326.5 & 43.0 & 276.9 & 36.5 & 57.1 & 7.5 & 660.5 \\
15 & 279.7 & 42.6 & 257.8 & 39.2 & 33.8 & 5.1 & 571.3 \\
16 & 303.8 & 45.5 & 235.9 & 35.3 & 40.6 & 6.1 & 580.3 \\
17 & 275.5 & 42.9 & 247.3 & 38.5 & 35.0 & 5.5 & 557.8 \\
\hline
\end{tabular}

Evapotranspiration of 4//8 type at intercropping stage under water shortage conditions

Table 6 shows, as same as monoculture alfalfa, the alfalfa high evapotranspiration period is between in the first crop and the second crop under full-irrigation conditions, however, the evapotranspiration ratio in the second crop is higher than monoculture alfalfa, in the stage, the evapotranspiration accounts for $49.43 \%$ and $41.92 \%$ of total amount of the whole growth period. The evapotranspiration of maize//alfalfa multistorey cropping forage grass should not be equal to the sum of evapotranspiration of both two plants, this shows that the planting pattern changes growth environment, the field evapotranspiration changes. Under full irrigation conditions, the low water treatment has a greater impact on branching-squaring and squaring-flowering stages; and has poor impact on emergence-branching stage.

\section{Influence of different water treatments on forage yield}

Table 7 shows, at different growth stages, different forages show various response to water stress, but which is eventually reflected by forage yield differences. Ass for monoculture maize, the influence of water shortages on yield reduction is the greatest at heading-milking stage, and is the lowest at sprouting-jointing stage. The influence of phased water shortage on the yield (grain) is in compliance with the following rules: Treatment $4>$ Treatment $3>$ Treatment $5>$ Treatment 2 , the maize requires less moisture at seedling stage; at the jointing stage, the impact of water deficit on yield is 
greater, in case of water shortage at jointing period, the yield reduction rate is $47.2 \%$; at the heading and milking stages, the maize transfers from vegetative growth to reproductive growth, leaf area index and evapotranspiration reach its highest value during the whole period, reproductive growth and metabolism is being vigorous; at flowering, pollination and milking stages, the output efficiency is the highest, lack of water has a greatest impact, the yield reduction rate is up to $51.7 \%$; after soft dough stage, the influence of water deficit on yield decreases gradually. At different stages, the water deficit treatment does not significantly affect moisture production efficiency of monoculture maize, which is basically the same between Treatment 1 and Treatment 2, Treatment 3 is slightly lower than Treatment 5, the influence of Treatment 4 is maximum.

Table 7. Analysis on forage yield under different water treatments

\begin{tabular}{c|c|c|c|c}
\hline Treatments & $\begin{array}{c}\mathbf{E T} \\
(\mathbf{m m})\end{array}$ & $\begin{array}{c}\text { Total yield } \\
\left(\mathbf{d r y} \text { weight } \mathbf{~ k g} / \mathbf{h m}^{\mathbf{2}}\right)\end{array}$ & $\begin{array}{c}\text { Moisture production } \\
\text { efficiency }\left(\mathbf{k g} / \mathbf{m}^{\mathbf{3}}\right)\end{array}$ & $\begin{array}{c}\text { Yield reduction rate } \\
(\boldsymbol{\%})\end{array}$ \\
\hline 1 & 600.6 & 13250.0 & 2.2 & - \\
2 & 510.5 & 11316.7 & 2.2 & 17.1 \\
3 & 438.4 & 9000.0 & 2.1 & 47.2 \\
4 & 450.5 & 8733.4 & 1.9 & 51.7 \\
5 & 480.5 & 10316.7 & 2.1 & 28.4 \\
\hline 6 & 726.7 & 21150.0 & 2.9 & - \\
7 & 592.9 & 16031.7 & 2.7 & 24.2 \\
8 & 579.7 & 13472.6 & 2.3 & 36.3 \\
9 & 583.1 & 14212.8 & 2.4 & -8 \\
\hline 14 & 660.5 & 2636.8 & 0.399 & 19.0 \\
15 & 571.3 & 2136.8 & 0.289 & 35.3 \\
16 & 580.3 & 1706.9 & 0.294 & 35.8 \\
\hline 17 & 557.8 & 1693.9 & 0.304 & \\
\hline
\end{tabular}

As for monoculture alfalfa, when the water shortage is implemented at emergencebranching stage (the lower limit of soil moisture content is lower than 50\%), the impact on the yield is minimum, the yield reduction rate is $24.2 \%$, indicating under normal emergence seedling conditions, appropriate water shortage does not impact later yield; the branching- squaring stage is a critical period of alfalfa physiological change, water shortage has the greatest impact on later yield, the yield reduction rate is $36.35 \%$; during the squaring-flowering period, the influence of water shortage on the total yield decreases, the yield reduction rate is $32.8 \%$. under different moisture treatment conditions, if the water supply is sufficient, the water production efficiency of monoculture alfalfa is the highest, and $6.89 \%$ higher than that of water shortage at sprouting-branching stage, $20.69 \%$ higher than that of water shortage at branchingbudding stage, and $17.24 \%$ higher than that of water shortage at budding-- flowering stage.

As for the intercropping maize/alfalfa, alfalfa has a longer growth period, under nonfull irrigation experimental design is mainly base on phased water supply in alfalfa growth period. By conversion to the crude protein content in maize/alfalfa final product within one year, it is available to conclude that the water shortages at squaring- 
flowering stage has the greatest impact on crude protein yield under intercropping conditions under different water treatments, which is different with the maximum influence period from water shortage of monoculture alfalfa of branching-squaring stage, indicating two kinds of forages jointly change the rules of nutrition production of the whole groups of plants in farmland.

\section{Conclusions}

As the main dairy forage, maize and alfalfa are completely different in water demands. During the whole growth period, the water demand rules of maize is a single peak parabola; during a growing season, the water demand rules of alfalfa shows multiple peaks as times of mowing increase; The evapotranspiration of maize//alfalfa multistorey cropping forage grass should not be equal to the sum of evapotranspiration of both two plants, the rules of water demand change greatly, showing a wavy undulating state. compared to evapotranspiration of monoculture maize and monoculture alfalfa, the variation of evapotranspiration of maize//alfalfa multi-storey cropping forage groups is not very significant.

As for monoculture maize, the influence of phased water shortage on the yield is maximum at the jointing-heading and heading-milking stages (moisture sensitive period); the influence of phased water shortage is minimum at emergence-jointing stage; as for monoculture alfalfa, during the squaring-flowering and branching-squaring period (moisture sensitive period), the influence of phased water shortage on the yield is maximum; at emergence (seedlings establishment)-jointing stage, the influence of phased water shortage is minimum; as for 4//8-type multi-storey cropping, at the branching-jointing stage of alfalfa, the influence of phased water shortage on the yield is maximum, which is greatly different with monoculture alfalfa.

In future studies, in order to meet the requirements of large-scale popularization and application of multi-storey cropping, further test deepening, technology integration and demonstration of various technologies still need to be implemented., technological maturity and farmers' planting level need to be improved, and technological maturity and farmers' planting level need to be improved.

Acknowledgements. This research was supported by the Special funds projects of China Institute of water resources and Hydropower Research (MK2018J07, MK2017J05, MK2016J10), National Natural Science Foundation of China (51469024), National key research and development program (2018YFD0300400), Inner Mongolia Science and Technology Project (201701024).

\section{REFERENCES}

[1] Chen, Y., Sun, J. (1997): Research on soil moisture control standards of water-saving irrigation. - Irrigation and Drainage 16(1): 24-28.

[2] Guo, K., Li, H., Shi, H. et al. (2005): Research on optimization of water-saving irrigation system and evapotranspiration of forage crop in $\mathrm{Mu}$ Us sandland. - Irrigation and Drainage 2: 24-27.

[3] Li, J., Wu, F., Fan, Y. (2003): Research on water-saving irrigation index and development mode. - Water-Saving Irrigation 5: 14-15. 
[4] Liu, H., Yin, C., Wei, Y., Zhang, R., Gao, T. (2016): Water production function of artificial grassland crop in arid desert area of Northern Xinjian. - Agric. \& Life Sci., Journal of Zhe Jiang University 42(2): 169-178.

[5] Wang, X., Ma, Y., Li, J. et al. (2003): Nutrients and biological characteristics of alfalfa. Pratacultural Science 10: 39-40.

[6] Zhang, X., Pei, D., Hu, C. (2002): Research on irrigation index of winter wheat and summer maize on Taihang Piedmont Plain. - CSAE 18(6): 36-41.

[7] Zhao, S., Guo, K., Su, P. (2008): Comprehensive benefit evaluation on dairy forage under different cropping patterns. - Water Economy 26(6): 41-44.

[8] Zhou, X., Luo, Q., Qu, B. (2005): Current situation and future development trends of China's dairy industry. - Contemporary Animal Husbandry 12: 1-3.

[9] Liu, H., Wei, Y., Guo, K. (2013): Water requirement and its law of silage corn in northern Xinjiang arid desert grassland. - Chinese Agricultural Science Bulletin 29(33): 94-100. 